\title{
Pancreatic Alpha Cell Adenoma
}

National Cancer Institute

\section{Source}

National Cancer Institute. Pancreatic Alpha Cell Adenoma. NCI Thesaurus. Code C67455.

A benign endocrine neoplasm arising from the alpha cells of the pancreas. It produces glucagon. 